\title{
From the Gutenberg Bible to COVID-19
}

\section{Carlos Ivan Simonsen Leal ${ }^{1}$}

1 President of Fundação Getulio Vargas, Rio de Janeiro / RJ - Brazil

The world after the COVID-19 pandemic will change, from the perspective of both geopolitical and economic challenges. There will be atendency for globalization to reverse, affecting theinternational position of several countries. The phenomenon of expanding the heavy use of information technology will mark the dynamics of many countries, including Brazil. Therefore, academia has to reflect on long-term strategies to create and maintain jobs while the economic structure changes.

Keywords: COVID-19; information technology; public administration.

\section{Da Bíblia de Gutenberg à COVID-19}

O mundo após a COVID-19 será diferente do mundo de antes, não apenas do ponto de vista dos desafios econômicos, mas também na perspectiva da geopolítica. A globalização tenderá a ser revertida, comclaras implicações para a posição dos vários países. O fenômeno da expansão do uso generalizado da tecnologia da informação marcará a dinâmica de vários países, inclusive do Brasil. A academia precisa refletir sobre estratégias de longo prazo para criar empregos e sustentar a empregabilidade enquanto a estrutura da economia se modifica.

Palavras-chave: COVID-19; tecnologias de informação; administração pública.

\section{De la Biblia de Gutenberg a la COVID-19}

El mundo después de la COVID-19 será diferente del anterior, no solo desde el punto de vista de los desafíos económicos, sino también desde la perspectiva de la geopolítica. La globalización tenderá a revertirse, con claras implicaciones para la posición de los distintos países. El fenómeno de expansión del uso generalizado de la tecnología de la información caracterizará la dinámica de varios países, inclusive de Brasil. La academia necesita reflexionar sobre estrategias a largo plazo para crear empleos y mantener la empleabilidad mientras la estructura de la economía se modifica.

Palabras clave: COVID-19; tecnologías de información; administración pública. 


\section{INTRODUCTION}

The year 2020 began with the trauma of a terrible plague, a situation humanity has not faced for a hundred years. COVID-19, a disease caused by a new, highly contagious and often lethal coronavirus, spread rapidly around the world. With no vaccine to immunize populations, governments worldwide had to appeal to the population to stay in confinement in an attempt to stop the spread of the disease.

The fight against the disease goes beyond the work of medical teams. It is, above all, an issue to be addressed by public management. Without a vaccine or proven effective drug, it has become essential to ensure that the health system can deal with the most serious cases, with the appropriate means. A new expression, "social distancing," entered our jargon, reflecting a set of measures with harmful consequences for the society as a whole.

It is the first time an experiment of this kind and magnitude has been attempted, which is possible due to the Internet and the developments it has brought. If today billions of people can be confined to their homes, it is because, even if in a restricted way, they have access to goods and services, and can, at least in part, work remotely.

This article will confirm the widespread notion that the world after COVID-19 will be different from the world before. The certain worsening of the economic situation will not be the only change. The global geopolitical panorama will also be transformed, and the world will be less secure. There will be a tendency for globalization to be reversed, and the dependence of global production chains on the Chinese industry is expected to fall, slowing that country's growth.

This will be a profound and long-term change due to the compulsory learning and use of multiple communication software providing simultaneous interaction and instruments for planning, executing, and evaluating tasks.

The fear of contamination has placed billions of people in social distancing, which forced many to use tools such as the Microsoft Teams ${ }^{\oplus}$, Zoom ${ }^{\oplus}$, Google Meet ${ }^{\oplus}$, and dozens of others, to hold meetings. These instruments, fortunately, already existed. They are the result of a slow and gradual evolution that has been expanding transversal communication among human beings. Because of the pandemic, they have now become widely used, first by companies and education systems, in a phenomenon, which will have many consequences in the future. This particular event should bring about a profound change in human development and the relative position of nations.

Few changes have been as relevant as this will likely be in the history of humankind. They do, however, have one feature in common: the ability to communicate remotely, whether in space or time.

The development of the writing system, the first of these major changes, allowed facts to be recorded and preserved. The introduction of alphabets to represent phonemes that form words and translate ideas was the key to simplify writing and disseminate its use. It also accustomed the human brain to think of the abstract more naturally.

In the fifteenth century (1439-40), Johannes Gensfleisch zur Laden zum Gutenberg revolutionized paper printing technology by inventing the first printer with sufficient operational flexibility to produce printed material and books at an affordable cost to the nascent urban bourgeoisie. His most famous success was certainly what was called the Gutenberg Bible, the name by which Johannes came to be known in history. 
The availability of printing became increasingly accessible since then. This technology allowed the dissemination of knowledge and contributed to an explosive historical event: Protestantism, led by Martin Luther rebelled against the Catholic Church. Among the main characteristics was seeking to learn God's will directly from reading the Bible. The combination of the technology that offered cheap printing, and the Protestants' demand for literature that represented their own salvation, led to literacy in the northern part of Europe. The consequence of these developments was the growth of the exchange of ideas and the advance of Science and Technology in the following centuries. It was a gigantic revolution.

Since the end of World War II, the complexity of human processes has constantly increased, as a result from both technological developments and social and political changes. Three overlapping macro movements stand out. The first movement originated in the US, which rationally invests in its war industry, given the growing need to optimize the use of scarce resources in increasingly complex systems. The second movement probably began shortly after the second oil crisis in 1978 . It is a phase of innovation on several layers: more rational use of energy, high-interest rates to fight inflation (in the US), and China starts emerging as a relevant economic player. This was the beginning of a new wave of globalization. The dissemination of information technology profoundly influenced managerial practices, offering agility. The third movement is marked by the extensive penetration of mobile communication, by smartphones, closely followed by the internet of things, radically changing the relationship between Information and Intelligence.

In Brazil, it is clear that the first movement was barely completed in most economic sectors and sub-sectors, and only a small fraction of the economy did the second. As for the third movement, essential points that should be concluded are not under execution.

Brazil's gradual and continuous loss of productivity in relation to developed nations, a process that has lasted for about 40 years, has its roots in this phenomenon. This is especially damaging when looking at the service sector. Today, representing $65 \%$ of the economy, it is irremediably condemned to obsolescence and has low added value.

Only in agribusiness and about two or three subsectors, was the country able to surpass competitiveness the average of the developed world. This has caused the growth of middle-class income to stagnate, leading the country to fall into the so-called middle- income trap.

The low level of productivity in the service sector is usually presented as an inevitable consequence of the low educational level. This is partly true. However, it is also a consequence of low integration with the industrial sector and a comprehensive inability of creating competitive organizations, capable of effectively executing complex projects. The current situation is criticized, stating that the country intends to have a 'service sector formed by pizza delivery people.'

As education takes decades to change, it could be assumed that all is lost. This article's point of view is that a Fourth Movement is just starting, and it is crucial for the country not to be left behind. This movement will consist of a disruptive evolution in the public and service sectors, due to an increase in productivity.

The impact of the new tools will be directly linked to the way we manage things. The way we think will change, creating immense opportunities and huge challenges. The acceleration of innovations, 
especially team-led innovations, and the consequent increase in competition will be tremendous. Processes will be profoundly altered, with immense consequences for productivity and employment.

\section{OPPORTUNITIES AND CHALLENGES IN THE POST-PANDEMIC WORLD}

This evolution of the facts indicates the indisputable increase in the use of information technology. Tasks are automated progressively. From the mechanization of administrative activities, such as accounting records, to manufacturing, humans have been replaced by computers. This was not necessarily bad; the increase in productivity freed up human resources for other tasks and allowed cheaper production. However, some challenges cannot be ignored (Leal, 2020).

This space is not suitable for analyzing the profound implications of a technological revolution of this kind for the general balance of an economy. Even so, it is necessary to warn that there is a current and strong pressure to reduce costs, and the intensive use of these tools, which increase such pressure, will occur. This could lead to initial unemployment that can be extended after the crisis generated by the COVID-19 pandemic.

These tools increase the added value of the upper layers of the command chain and decrease, at least in relative terms, the value of the lower ones. Thus, they potentially have an income-concentrating effect and can reduce the aggregate demand of an economy.

However, they somehow create a greater leveling of Brazil with the rest of the world since the country stops competing based on the average education of the general population, and starts to compete based on the average education of those in an upper layer in the command chain.

At a time when the tendency is for deglobalization of the world economy, the increase in productivity in Brazil, a country which still has a closed domestic economy but an exporter of food, oil, and minerals, could create a relevant rapid growth cycle in relation to the rest of the world.

To try to avoid this modernization would be foolish. It is like rejecting computers to keep typists. The rest of the world will move forward, so Brazil must move forward too.

Therefore, a long-term strategy will be needed to create jobs and sustain employability while the structure of the economy changes. This movement will not be easily constructed. On the contrary, many educational, social, and political paradigms will have to be modified. 


\section{REFERENCE}

Leal, C. I. S. (2020, May-June). Um problema para a gestão pública. GV-executivo, 19(3), 6-9.

\section{Carlos Ivan Simonsen Leal}

https://orcid.org/0000-0002-4304-2847

Professor Simonsen Leal is the President of Fundação Getulio Vargas since 2000. Civil Engineer, he graduated in 1980 from the School of Engineering of the Federal University of Rio de Janeiro (UFRJ), and chose the academic life obtaining, in 1982, a master's degree in Mathematical Economics from the Institute for Pure and Applied Mathematics (Impa), a doctorate degree from the Brazilian School of Economics and Finance of the Fundação Getulio Vargas (FGV EPGE) (1980-1982), and a Ph.D. in Economics from Princeton University (USA) in 1986. He was a professor of Macroeconomics, Microeconomics, and Public Finance at the FGV EPGE in 1986. Professor Simonsen Leal was a consultant for the Central Bank of Brazil in 1989, and held different positions at FGV: Dean of FGV Business, 1992-1994; Dean of FGV EPGE, 1994-1997, and Vice-president of FGV, 1997-2000. In 2002, he was awarded the title of Grand Cross of the National Order of Scientific Merit by the President of Brazil, for his contribution to Science and Technology. In 2008, he was granted by the Republic of France with the Palmes Académiques. Other honorific titles and awards received include the Judicial Medal awarded by the Court of Justice of the State of Rio de Janeiro (2009), Professor Emeritus of the Army Command and General Staff College, Peacemaker Medal of the Brazilian Army (2010), Order of Naval Merit (2013), Titular member of the Brazilian National Academy of Engineering (2013), Honorary Submariner Certificate (2013), Eminent Engineer Diploma from Polytechnic School (2014), Merit Medal “Tamandaré" (2014), Diploma of Aeronaval Merit (2016), Medal of Statistical Merit "Mário Augusto Teixeira de Freitas" (2016) from the Brazilian Institute of Geography and Statistics, Medal of the Brazilian Army (2017), Honorary Hydrographer from the Brazilian Navy (2017), Medal of the Order of Military Merit awarded by the Brazilian Army (2018), Order of Naval Merit awarded by the Brazilian Navy (2019), and Commendation of the Order of Aeronautical Merit (2019). 